http://dx.doi.org/10.18778/1509-877X.2017.04.02

Artykuły

Stefan Babiarz ${ }^{*}$

\title{
Glosa do wyroków Trybunału Konstytucyjnego Z DNIA 18 KWIETNIA 2018 R. K 52/16 ORAZ Z DNIA 10 LIPCA 2000 R. SK 12/99²
}

\begin{abstract}
Streszczenie. Oba glosowane wyroki Trybunału Konstytucyjnego - w sprawach K 52/16 i SK 12/99 - należy uznać za nietrafne. Ten drugi wyrok jest niejako konsekwencją tego pierwszego. Teza pierwszego wyroku została sformułowana zbyt szeroko, a powinna być ograniczona tylko do sytuacji, w której przepisy prawa administracyjnego wprost nie chronią danej należności i nie przyznają tej ochronie drogi sądowej. Ta sytuacja doprowadziła do rozszerzenia kompetencji Sądu Najwyższego i sądów powszechnych na kolejne instytucje prawa cywilnego w sytuacji, gdy przepisy prawa podatkowego taką drogę ochrony, w tym drogę przed sądami administracyjnymi, przewidują. Trudno na tym etapie - mimo ukształtowanej przez kilkanaście lat jednolitej linii orzeczniczej sądów powszechnych i Sądu Najwyższego - przesądzić ten kierunek orzeczniczy. Tylko droga przed Trybunałem Sprawiedliwości Unii Europejskiej albo ingerencja ustawodawcy może ten niekorzystny kierunek orzecznictwa zmienić.
\end{abstract}

Słowa kluczowe: skarga pauliańska, dominium, imperium, należności publicznoprawne.

1. Pierwszy z glosowanych wyroków zapadł na skutek wniosku Rzecznika Praw Obywatelskich (dalej: Rzecznik), który skierował do Trybunału Konstytucyjnego 1 grudnia 2016 r. wniosek o stwierdzenie, że ,art. $527 \$ 1$ ustawy z dnia 23 kwietnia 1964 r. - Kodeks cywilny ${ }^{3}$, w zakresie, w jakim znajduje zastosowanie na zasadzie analogii legis do dochodzenia należności

\footnotetext{
* Sędzia Naczelnego Sądu Administracyjnego, e-mail: sbabiarz@nsa.gov.pl

${ }^{1}$ OTK-A 2018, poz. 28; Dz.U. z 2018 r., poz. 760.

2 OTK 2000, nr 5, poz. 143; Dz.U. z 2000 r. Nr 55, poz. 665.

3 Dz.U. z 2016 r., poz. 380 z późn. zm.; dalej: k.c.
} 
publicznoprawnych na drodze cywilnej w formie skargi pauliańskiej, jest niezgodny z art. 2 oraz art. 84 Konstytucji”. Swój pogląd Rzecznik oparł na następujących przesłankach:

a) skarga pauliańska jako instytucja prawa cywilnego może chronić tylko i wyłącznie wierzytelności prywatnoprawne, a inaczej mogłoby być, gdyby przewidywał to wyraźny przepis prawa;

b) zasada zaufania obywatela do państwa i stanowionego przez nie prawa, zasada pewności bezpieczeństwa prawnego, nakaz respektowania reguł przyzwoitej legislacji w odniesieniu do aktów prawnych ograniczających wolności i prawa obywatelskie oraz nakładających podatki, uzasadniają, zdaniem Rzecznika, pogląd, że wzorcem kontroli konstytucyjności art. 527 $\$ 1$ k.c. powinien być art. 2 Konstytucji;

c) zasada poprawnej legislacji została naruszona bowiem w drodze trwałej, powszechnej i jednolitej, poczynając od wyroku Trybunału Konstytucyjnego z dnia 19 lipca 2000 r., SK 12/994 oraz postanowienia SN z dnia 16 kwietnia 2002 r., IV CK 41/02 5 i uchwały 7 sędziów SN z dnia 11 kwietnia 2003 r., III CZP 15/036 , wykładni art. $527 \$ 1$ k.c. nadano znaczenie, zgodnie z którym przepis ten może być stosowany do ochrony należności publicznoprawnych, natomiast takie jego rozumienie nie wynika z obowiązujących przepisów prawa, w szczególności z przepisów kodeksu postępowania cywilnego i ustawy - Ordynacja podatkowa;

d) zasada powszechności obciążeń publicznych jako podstawa władztwa daninowego państwa i wymóg uregulowania przez ustawodawcę wszystkich podstawowych elementów obowiązku daninowego w sposób kompletny, precyzyjny i jednoznaczny, obowiązek wprowadzenia przez państwo takich gwarancji instytucjonalnych zapewniających organom wykonawczym kontrolę prawidłowego wywiązywania się z obowiązków daninowych - uzasadniają wskazanie jako wzorca kontroli także art. 84 Konstytucji;

e) w prawie podatkowym obowiązuje zasada ograniczonego stosowania analogii jako konsekwencja stosowania zasady in dubio pro tributario, a to oznacza, że jest ona niedopuszczalna na niekorzyść podatnika, jeżeli jej skutkiem musiałoby być nałożenie na podatnika obowiązku podatkowego, zawężenie reguł gwarancyjnych lub osłabienie ochrony praw i wolności obywateli;

${ }^{4}$ OTK 2000, nr 5, poz. 143; Dz.U. z 2000 r. Nr 55, poz. 665.

${ }^{5}$ OSP 2003, nr 2, poz. 22, z glosą krytyczną P. Machnikowskiego, ibidem.

${ }^{6}$ OSNC 2004, nr 3, poz. 32. 
f) należności publicznoprawne to nie wierzytelności, o których mowa w art. $527 \$ 1$ k.c., a dla ich ochrony ustawodawca przewidział odrębne instytucje w ustawie z dnia 29 sierpnia 1997 r. - Ordynacja podatkowa ${ }^{7}$ w rozdziale 15 Działu III, na zasadzie regulacji zamkniętej;

g) organy podatkowe dysponują poza tym szeregiem środków prawnych, których celem jest ochrona należności publicznoprawnych, takich jak: zabezpieczenie $\mathrm{z}$ art. 33 ord. pod., zabezpieczenie egzekucyjne (art. 154 ustawy z dnia 17 czerwca 1966 r. o postępowaniu egzekucyjnym $\mathrm{w}$ administracji $)^{8}$; nadanie nieostatecznej decyzji podatkowej rygoru natychmiastowej wykonalności (art. $239 \mathrm{~b} \$ 1$ pkt 2 ord. pod.); wniosek o nakazanie wyjawienia majątku na podstawie art. 71 u.p.e.a., przyznawanie im jeszcze dodatkowego środka prawnego jest uprzywilejowaniem należności publicznoprawnych w stosunku do należności prywatnoprawnych;

h) państwo, działając w sferze władczej (imperium), nie powinno bez wyraźnej podstawy prawnej sięgać po środki charakterystyczne dla ochrony wierzytelności cywilnoprawnych, a praktyka - sięgając do stosowania art. $527 \$ 1$ k.c. do ochrony należności publicznoprawnych - doprowadziła do rozszerzenia uprawnień państwa, co skutkuje jego uprzywilejowaną pozycją i podważa stan bezpieczeństwa prawnego osoby trzeciej, działającej jako uczestnik obrotu, w sytuacji gdy mechanizm samoobliczania podatku i ograniczone możliwości tej osoby weryfikacji sytuacji podatkowej dłużnika, z uwagi na przepisy o tajemnicy skarbowej, stawiają ją w niepewnej sytuacji i stanowią dla niej pułapkę.

2. Trybunał Konstytucyjny w wyroku z dnia 18 kwietnia 2018 r., K 52/16, orzekł, że „art. $527 \$ 1$ k.c. w zakresie, w jakim znajduje zastosowanie na zasadzie analogii legis do ochrony należności publicznoprawnych, jest zgodny z art. 2 Konstytucji Rzeczypospolitej Polskiej”. Wedle uzasadnienia wyroku za poglądem tym przemawiają - zdaniem Trybunału Konstytucyjnego - następujące okoliczności:

a) argumenty Rzecznika odnoszące się do uprzywilejowania Skarbu Państwa w sferze władztwa podatkowego, w sferze wyposażenia go w dodatkowy instrument nieprzewidziany wprost w ustawie, w sferze zaskakiwania osób trzecich nie są przekonujące, gdyż organ podatkowy nie działa tu władczo, nie wykonuje właściwego mu imperium, ale działa jako podmiot prawa prywatnego dochodzący owych praw;

\footnotetext{
7 Dz.U. z 2017 r., poz. 201 z późn. zm.; dalej: ord. pod.

${ }^{8}$ Dz.U. z 2017 r., poz. 1201 z późn. zm.; dalej: u.p.e.a.
} 
b) wydany w procesie z powództwa Skarbu Państwa wyrok nie rodzi nowych podatkowoprawnych stanów faktycznych, podlegających opodatkowaniu i nie rozszerza zakresu opodatkowania, a stwarza jedynie wierzycielowi możliwość przeprowadzenia w przyszłości skutecznej egzekucji należności publicznoprawnej, a w tym celu wierzyciel musi dysponować nie tylko orzeczeniem stwierdzającym bezskuteczność czynności prawnej dokonanej między dłużnikiem a osoba trzecią, lecz także administracyjnym tytułem wykonawczym przeciwko dłużnikowi';

c) skarga pauliańska nie kreuje zatem nowej sytuacji prawnomaterialnej w sferze prawa podatkowego, nie nakłada bowiem na osobę trzecią nieznanej prawu podatkowemu daniny, a obowiązek, jaki nakłada na te osobę, polega na nakazie znoszenia egzekucji skierowanej do korzyści, którą powinny uzyskać wskutek czynności prawnej dokonanej z dłużnikiem z pokrzywdzeniem powoda;

d) powyższe oznacza, że nie można się zgodzić, iż art. $527 \$ 1$ k.c. jest formą uprzywilejowania państwa wobec obywateli i że stanowi nieznaną prawu publicznemu instytucję, gdyż sąd stwierdzając na podstawie tego przepisu bezskuteczność umowy zawartej między dłużnikiem publicznoprawnym i osobą trzecią, nie wkracza w ogóle w obszar uprawnień i obowiązków podatkowych o charakterze materialnoprawnym osoby trzeciej (pozwanego);

e) wyrok Trybunału Konstytucyjnego nie narusza wymogów poprawnej legislacji, gdyż ustawodawca - w akcie normującym zagadnienie wymagające wyższego „standardu jednoznaczności i określoności przepisów” (prawo podatkowe) - nie odsyła do regulacji, której standard ten jest niższy, a poza tym ten wyższy standard odnosi się do unormowań będących podstawą kształtowania zobowiązania podatkowego i określania jego wysokości, a w sprawie $\mathrm{z}$ art. $527 \$ 1$ k.c. nie dochodzi do kształtowania, weryfikacji czy modyfikacji zobowiązania podatkowego;

f) Trybunał Konstytucyjny nie podziela też zarzutu Rzecznika, że kwestionowana przez niego regulacja narusza zasadę zaufania jednostki do państwa i stanowionego przez nie prawa oraz że jest pułapką dla obywatela, albowiem przeciwko temu poglądowi przemawiają przesłanki stosowania skargi pauliańskiej, należyta staranność, domniemania dotyczące świadomości osoby trzeciej, a istnienie tajemnicy skarbowej także nie przemawia za tym

9 Wyrok SN z dnia 28 października 2019 r., II CSK 227/10, OSNC-ZD 2011, nr 1, poz. 23. 
stanowiskiem, gdyż kontrahenci w obrocie cywilnoprawnym na ogół nie dysponują możliwością zweryfikowania stanu majątkowego kontrahenta;

g) jednolita i ugruntowana linia orzecznicza sądów powszechnych, a także Sądu Najwyższego, mająca kilkanaście lat, także przemawia za tym, że omawiana regulacja nie stanowi dla osoby trzeciej „pułapki” zastawionej na (uczciwego) uczestnika obrotu;

h) analogia legis w stosowaniu art. $527 \$ 1$ k.c. do ochrony należności publicznoprawnych nie jest przypadkiem analogii w prawie podatkowym, ale przypadkiem ochrony tych należności i nie narusza zasad prawidłowej legislacji, w tym określoności przepisów, a poza tym zakres znaczeniowy pojęcia wierzytelności, a więc to, czy obejmuje on także należności publicznoprawne, budzi kontrowersje, ale przesądzenie jej i tak nie jest konieczne dla rozstrzygnięcia sprawy, gdyż charakter należności z punktu widzenia oceny czynności prawnej krzywdzącej wierzyciela może być uznany za obojętny;

i) wprawdzie można uznać, że rozpatrywana analogia narusza tradycyjny podział prawa na prawo prywatne i prawo publiczne, lecz to na tle zasady zaufania do państwa i stanowionego przez nie prawa, czy zasady określoności prawa, nie ma znaczenia dla rozstrzygnięcia sprawy, gdyż wypracowane w orzecznictwie Trybunału Konstytucyjnego kryteria oceny naruszenia tych zasad mają charakter uniwersalny i dotyczą tak przepisów prawa prywatnego, jak i publicznego;

j) naruszenie zasady określoności przepisów, rozumiane jako możliwość konstruowania na ich gruncie jednoznacznych norm prawnych i jednoznacznych ich konsekwencji za pomocą reguł rozumowania prawniczego, przyjmowanych na gruncie określonej kultury prawnej ${ }^{10}$, może doprowadzić do pozbawienia mocy obowiązującej przepisu tylko wyjątkowo (środek ostateczny) i to w sytuacji, gdy wynikających z niejasności przepisu rozbieżności w jego interpretacji nie da się usunąć za pomocą zwykłych metod niejednolitości stosowania prawa;

k) analogiczne stosowanie art. $527 \$ 1$ k.c. do należności publicznoprawnych nie narusza też zasady ograniczonej (ostrożnej) analogii w prawie podatkowym, albowiem nie tworzy ono nowych podatkowoprawnych stanów faktycznych podlegających opodatkowaniu, skoro nie można $\mathrm{z}$ tej instytucji wywodzić żadnego nowego obowiązku podatkowego;

${ }^{10}$ Wyrok TK z dnia 7 kwietnia 2011 r., K 4/09, OTK-ZU 2011, nr 3, poz. 20; wyrok TK z dnia 16 grudnia 2003 r., SK 34/03, OTK-A 2003, nr 9, poz. 102. 
1) art. 84 Konstytucji jest nieadekwatnym wzorcem konstytucyjnym, gdyż statuuje on zasadę powszechności obowiązków publicznych, z których wynika powinność obywateli należytego wykonania obowiązku daninowego, jak również obowiązek państwa wprowadzenia instytucjonalnych gwarancji zapewniających organom państwa kontrolę i egzekwowanie wykonywania przez podatników ich obowiązków fiskalnych, gdyż zakres zastosowania instytucji skargi pauliańskiej jest inny niż zakres normatywny art. 84 Konstytucji, a to oznacza, że między nimi nie zachodzi ani zgodność, ani niezgodność, co spowodowało konieczność umorzenia postępowania na podstawie art. 53 ust. 1 pkt 2 ustawy z dnia 30 listopada 2016 r. o organizacji i trybie postępowania przed Trybunałem Konstytucyjnym ${ }^{11}$.

3. Teza oraz uzasadnienie zawarte w glosowanym wyroku Trybunału Konstytucyjnego nie zasługują na aprobatę. Jednakże to samo należy stwierdzić o wniosku Rzecznika i jego uzasadnieniu, a także o wyroku Trybunału Konstytucyjnego z dnia 19 lipca 2000 r., SK 12/9912. Po pierwsze o wniosku powiedzieć trzeba, że Rzecznik nie zawarł w nim wszystkich możliwych, wchodzących w rachubę, wzorców kontroli konstytucyjnej, a należało to uczynić choćby dlatego, że glosowany wyrok jest chyba pierwszym wyrokiem Trybunału Konstytucyjnego odnoszącym się do instytucji prawnej osób trzecich odpowiedzialnych za zaległości podatkowe podatnika (płatnika i inkasenta oraz następcy prawnego). Taka sytuacja wymagała choćby kompleksowego przedstawienia tej instytucji prawnej, albowiem można było się spodziewać, że wyrok ten może w przyszłości ukształtować rozumienie zasad odpowiedzialności osób trzecich. Jest przy tym rzeczą oczywistą, że Trybunał Konstytucyjny nie mógł we własnym zakresie rozszerzyć granic wniosku o zbadanie konstytucyjności art. $527 \$ 1$ k.c. z innymi wzorcami konstytucyjnymi. Po drugie, wniosek, a w konsekwencji także glosowany wyrok, niejako z góry i a priori założyły, że wyrok Trybunału Konstytucyjnego z dnia 10 lipca 2000 r., SK 12/99, stanowi „fundamentalną wytyczną dla szerokiego rozumienia sprawy cywilnej i w konsekwencji dał asumpt do zmian poglądów prezentowanych w orzecznictwie na temat dopuszczalności cywilnej drogi sądowej w sprawach, w których Skarb Państwa dochodzi należności publicznoprawnych”. Zatem już punkt wyjścia Rzecznika, a w ślad za nim także Trybunału Konstytucyjnego, były

11 Dz.U. z 2016 r., poz. 2072; dalej: u.o.T.K.

12 OTK 2000, nr 5, poz. 143; Dz.U. z 2000 r. Nr 55, poz. 665. 
wadliwe, mimo że teza tego wyroku interpretacyjnego wydaje się z pozoru jednoznaczna. Otóż w piśmiennictwie dostrzega się, że w przypadku wyroków zakresowych (interpretacyjnych) należy najbardziej, jak to możliwe, precyzyjnie formułować sentencję ${ }^{13}$, a jest tak dlatego, że tylko sentencja podlega publikacji w dzienniku urzędowym, co ma kluczowe znaczenie z punktu widzenia zasady pewności prawa i domniemania jego powszechnej znajomości ${ }^{14}$. Wyrok interpretacyjny jest w piśmiennictwie ${ }^{15}$, a także w orzecznictwie Trybunału Konstytucyjnego ${ }^{16}$ rozumiany jako rozstrzygnięcie Trybunału Konstytucyjnego - o zgodności, niezgodności albo braku niezgodności - określające precyzyjnie zależność, relację pomiędzy przedmiotem kontroli czy przepisem prawa a jego wzorcem, normą konstytucyjną. Dlatego dla odkodowania normy wynikającej z interpretacji wyroku interpretacyjnego Trybunału Konstytucyjnego, mimo że nie ma ono waloru i przymiotu powszechnie obowiązującego, należy sięgać do jego uzasadnienia. Uzasadnienie orzeczenia obejmuje zaś przesłanki i argumenty, na których oparto ustalenia i rozstrzygnięcia Trybunału. Jest ono jednak niezdolne - jak przyjął Trybunał Konstytucyjny w orzeczeniu z dnia 5 listopada 1986 r., U 5/86 ${ }^{17}$ - niezależnie od orzeczenia, do samoistnego wywołania skutków, jakie ustawa o Trybunale Konstytucyjnym łączy z rozstrzygnięciem zawartym w sentencji. Oznacza to zatem konieczność dokonywania wykładni sentencji wyroku Trybunału Konstytucyjnego przez pryzmat jego uzasadnienia. W powołanym wyżej wyroku Trybunału Konstytucyjnego w sprawie SK 12/99 Trybunał stwierdził, że „art. 1 k.p.c.

${ }^{13}$ M. Więcek, S. Żółtek, Skutki wyroków TK o niekonstytucyjności przepisów prawa karnego materialnego, [w:] M. Bernatt, J. Królikowski, M. Ziółkowski (red.), Skutki wyroków Trybunału Konstytucyjnego w sferze stosowania prawa, „Studia i Materiały Trybunału Konstytucyjnego", t. XLVII, Warszawa 2013, s. 26-27.

${ }^{14}$ Ibidem.

15 Zob. W. Białogłowski, Wznowienie postępowania $w$ następstwie wydania przez TK wyroku interpretacyjnego, [w:] M. Bernatt, J. Królikowski, M. Ziółkowski (red.), Skutki wyroków Trybunału Konstytucyjnego w sferze stosowania prawa, „Studia i Materiały Trybunału Konstytucyjnego", t. XLVII, Warszawa 2013, s. 198; L. Garlicki, Uwagi o charakterze prawnym orzeczeń Trybunału Konstytucyjnego, [w:] B. Banaszak, J. Trzciński (red.), Studia nad prawem konstytucyjnym, Wrocław 1997, s. 91; K. Pietrzykowski, O tak zwanych „interpretacyjnych” wyrokach Trybunału Konstytucyjnego, „Przegląd Sądowy” 2004, nr 3.

${ }_{16}$ Postanowienie TK z dnia 5 listopada 2001 r., T 33/01, OTK-ZU 2002, nr 1, poz. 47; uchwała składu 7 sędziów SN z dnia 17 grudnia 2009 r., III PZP 2/09, OSP 2010, nr 10, poz. 103; wyrok NSA z dnia 19 czerwca 2002 r., I SA/Łd 953/00, niepubl.

17 OTK 1986, poz. 1. 
rozumiany w ten sposób, iż w zakresie pojęcia «sprawy cywilnej» nie mogą mieścić się roszczenia dotyczące zobowiązań pieniężnych, których źródło stanowi decyzja administracyjna, jest niezgodny z art. 45 ust. $1 \mathrm{w}$ związku z art. 31 ust. 3 Konstytucji Rzeczypospolitej Polskiej”.

Zauważyć tu jeszcze należy, że asumpt do wystąpienia skarżącego w tejże sprawie ze skargą konstytucyjną dała odmowa przyznania mu odsetek należnych od przyznanego mu i niewypłaconego w terminie stypendium oraz nagrody rektorskiej, a także od zapomogi. Przepisy prawa administracyjnego nie zawierały podstawy prawnej do przyznania tych odsetek. Jak ustalił Trybunał Konstytucyjny, także inne przepisy prawa administracyjnego nie dopuszczały możliwości dochodzenia świadczeń pieniężnych należnych funkcjonariuszowi Policji, w tym także odsetek, a przewidzianych w rozdziale 9 ustawy z dnia 6 kwietnia 1990 r. o Policji18, powołując się przykładowo na uchwały SN z dnia 26 maja 1995 r., I PZP 13/95 ${ }^{19}$ oraz z dnia 18 grudnia 1992 r., III AZP 27/92 20 . Należy jednak mieć tu na uwadze to, czego Trybunał Konstytucyjny w sentencji wyroku w sprawie SK 12/99 nie wypowiedział wyraźnie, wbrew swemu obowiązkowi - że chodziło o sytuację, w której przepisy prawa administracyjnego nie regulowały, a więc w której nie przewidziały sądowej drogi ochrony praw jednostki. Sentencja tego wyroku interpretacyjnego została więc sformułowana zbyt szeroko, co Trybunał Konstytucyjny w pierwszym z glosowanych wyroków mógł poprawić, ale tego nie zrobił.

Zagadnienie dopuszczalności drogi sądowej w sprawie o ochronę należności odsetkowych funkcjonariuszy Policji, Urzędu Ochrony Państwa, Straży Granicznej było też przedmiotem rozważań Trybunału Konstytucyjnego w uchwale z dnia 25 stycznia 1995 r., W 14/94²1, w której Trybunał Konstytucyjny wyraźnie stwierdził i z ograniczeniem sentencji tylko do odsetek, że „niewypłacenie uposażenia (powyższym funkcjonariuszom) stanowi opóźnienie się ze spełnieniem świadczenia pieniężnego, uzasadniające na podstawie art. $481 \$ 1$ kodeksu cywilnego żądanie odsetek przed sądem powszechnym”. W tej sprawie Trybunał wyraźnie wskazał, że „brak wypowiedzi ustawodawcy w kwestii prawa do sądu, będącego jednym $\mathrm{z}$ fundamentalnych założeń demokratycznego państwa prawnego, wynikającego z ustrojowej aksjologii Rzeczypospolitej Polskiej, nie może być rozumiany

${ }^{18}$ Dz.U. z 2017 r., poz. 2067 z późn. zm.

19 OSNP 1995, nr 23, poz. 286; uchwała SN z dnia 18 grudnia 1992 r., III CZP 27/92, OSNCP 1993, nr 9, poz. 141.

${ }^{20}$ OSNCP 1993, nr 9, poz. 141.

${ }^{21}$ OTK 1995, nr 1, poz. 19; Dz.U. z 1995 r. Nr 14, poz. 67. 
jako wyłączenie drogi sądowej”22. Dlatego w orzecznictwie Naczelnego Sądu Administracyjnego przyjmuje się, respektując art. 177 Konstytucji $^{23}$, że „droga administracyjna w przedmiocie dochodzenia odsetek przysługuje tam, gdzie przepis określonej pragmatyki służbowej przewiduje prawo do odsetek, a jednocześnie nie zarezerwował dla ich dochodzenia drogi przed sądem powszechnym" ${ }^{24}$. Pogląd ten podzielają też inne sądy administracyjne ${ }^{25}$.

Wydając pierwszy z glosowanych wyroków i odwołując się do wyroku Trybunału Konstytucyjnego w sprawie SK 12/99, sąd nie zwrócił uwagi (zresztą Rzecznik także), że Trybunał Konstytucyjny w istocie w tym drugim wyroku uchylił się od zbadania konstytucyjności art. 1 k.p.c. z art. 177 Konstytucji, albowiem umorzył postępowanie w tym zakresie. Przepis ten określa się ,jako swoiste domniemanie drogi sądowej”. „Ustawodawcy przy tak sformułowanej normie konstytucyjnej pozostaje jedynie wybór między sądem powszechnym a sądem administracyjnym jako drogą sądową w określonej sprawie. Jeżeli nie ma wyraźnego wskazania, że sądem właściwym jest sąd administracyjny, należy przyjąć, że podmiot domagający się ochrony swych praw może zwrócić się do sądu powszechnego"26. Trybunał powołał się tutaj na przepis art. 79 ust. 1 Konstytucji, twierdząc, że art. 177 Konstytucji nie jest dla wnoszącego skargę źródłem wolności i praw podmiotowych. Tymczasem Trybunał Konstytucyjny nie zwrócił uwagi na to, że wejście w życie art. 177 w związku z art. 45 i art. 77 ust. 2 Konstytucji doprowadzić mogło do powstania sprzeczności miedzy nimi a art. 1 k.p.c. ${ }^{27}$. Poza tym w piśmiennictwie pojęcie „prawo podmiotowe” jest rozumiane różnie, najczęściej jako zespół uprawnień (rzadko jedno pojedyncze uprawnienie) służących jakiemuś podmiotowi prawnemu, bez wskazywania ich źródeł ${ }^{28}$. Nie zwrócił też

${ }^{22}$ Orzeczenie TK z dnia 25 lutego 1992 r., K 3/91, OTK 1992, cz. I, s. 34.

${ }^{23}$ Sądy powszechne sprawują wymiar sprawiedliwości we wszystkich sprawach, z wyjątkiem spraw ustawowo zastrzeżonych dla właściwości innych sądów.

${ }^{24}$ Wyrok NSA z dnia 3 lutego 2015 r., I OSK 1467/13, Lex nr 1956414.

25 Zob. wyrok WSA w Gdańsku z dnia 15 marca 2018 r., III SA/Gd 924/17, Lex nr 2477072; wyrok WSA w Gorzowie Wlkp. z dnia 28 października 2009 r., II SAB/ Go 53/09, Lex nr 573942; wyrok NSA z dnia 29 stycznia 2003 r., II SA 1643/02, Lex nr 151413; wyrok NSA z dnia 9 maja 2002 r., I SA 2419/00, Lex nr 81655.

${ }^{26}$ K. Flaga-Gieruszyńska, Glosa krytyczna do wyroku SN z dnia 26 czerwca 2001 r., III CZP 30/01, „Rejent” 2002, nr 6, s. 132.

${ }^{27}$ A. Zieliński, Prawo do sq̨du a struktura sądownictwa, PiP 2003, nr 4, s. 20-31.

${ }_{28}$ Tak np. T. Chauvin, T. Stawecki, P. Winczorek, Wstęp do prawoznawstwa, Warszawa 2009, s. 70; S. Wronkowska, Podstawowe pojęcia prawa i prawoznawstwa, Poznań 2005, s. 169. 
uwagi na to, że art. $58 \$ 1$ pkt 1 , art. $183 \$ 2$ pkt 1 ustawy z dnia 30 sierpnia 2002 r. - Prawo o postępowaniu przed sądami administracyjnymi ${ }^{29}$, a także art. $199 \$ 1$ pkt 1 k.p.c. stanowi, że sąd jest obowiązany rozpoznać sprawę tylko wówczas, gdy jest sądem właściwym. Oznacza to, że art. 45 ust. 1 Konstytucji mówi wyraźnie, że chodzi o prawo nie do jakiegokolwiek sądu, ale do sądu właściwego. Przy wykładni pojęcia prawa podmiotowego zatem należy uwzględniać także normę konstytucyjną z art. 177 Konstytucji. Wskazać tu jeszcze trzeba na kolejne zagadnienia tak rozstrzygnięcia, jak i uzasadnienia powyższego wyroku Trybunału Konstytucyjnego w sprawie SK 12/99, wiążące się z rozpoznawaną kwestią. Trybunał Konstytucyjny badał także postępowanie w zakresie konstytucyjności m.in. art. 2 k.p.c. $\mathrm{z}$ art. 2, art. 31 ust. 3 i art. 45 ust. 1 Konstytucji, stwierdzając, że są one zgodne z tymi konstytucyjnymi wzorcami, gdyż przepis art. 2 k.p.c. nie wytycza granic ochrony sądowej, a jest tylko konsekwencją unormowania zawartego w art. 1 k.p.c., albowiem „poprawne określenie sprawy cywilnej dokonane na gruncie art. 1 k.p.c. determinuje zakres właściwości sądów powszechnych określony w art. 2 k.p.c.". Nic dodać, nic ująć. Rzecz tylko w tym, że takie rozwiązanie problemu posłużyło Sądowi Najwyższemu w ramach „prowadzonej polityki” swej omnipotencji (oportet semper - 'zawsze właściwy') do rozszerzenia kompetencji orzeczniczych poprzez rozszerzające rozumienie określenia „sprawa cywilna” zawarte w art. 1 k.p.c.

Sąd Najwyższy w postanowieniu z dnia 16 kwietnia 2002 r., V CK 41/02 (notabene nawet nieopublikowanym w zbiorze urzędowym Sądu Najwyższego) odwrócił kierunek swego orzecznictwa w zakresie dopuszczalności drogi sadowej w sprawach o ochronę należności publicznoprawnych w drodze skargi pauliańskiej, co zresztą Trybunał Konstytucyjny w wyroku w sprawie K 52/16 dostrzegł. Nie dostrzegł jednak, że przyjęte przez Sąd Najwyższy, także w późniejszych orzeczeniach, w tym w uchwale z dnia 12 marca 2003 r., III CZP 85/02 ${ }^{30}$, rozszerzające (czego nie ukrywano) rozumienie tego pojęcia „sprawa cywilna” prowadzi do zburzenia równowagi kompetencyjnej sądów powszechnych i sądów administracyjnych. Podkreślić tu trzeba, że z uwagi na treść art. 177 w zw. z art. 15 ust. 1 i art. 2 Konstytucji można kwestionować pogląd zawarty w tym postanowieniu, że „działaniem lub zaniechaniem, którego skutki mogą być rozpoznawane na drodze sądowej przed sądem powszechnym, jest - oprócz zdarzeń cy-

\footnotetext{
29 Dz.U. z 2018 r., poz. 1302.

${ }^{30}$ OSNC 2003, nr 10, poz. 129.
} 
wilnoprawnych uregulowanych w kodeksie cywilnym, takich jak czynność prawna czy czyn niedozwolony - także akt administracyjny wywołujący skutki w zakresie prawa cywilnego (z uzasadnienia postanowienia SN w sprawie V CK 41/02)". Trafnie podniósł w krytycznej glosie do tego postanowienia P. Machnikowski ${ }^{31}$, że „pewne fakty (np. akty administracyjne) kwalifikujemy jako zdarzenia prawa cywilnego, gdyż są objęte hipotezą normy, której dyspozycja nakłada na adresata obowiązek określonego działania lub zaniechania względem innej osoby (tworzy stosunek prawny), a w układzie uprawnień i obowiązków składających się na ten stosunek nie występuje (w zasadzie przynajmniej) zjawisko władczego określenia przez jedną ze stron sytuacji prawnej (uprawnień) obowiązków drugiej. Takie bowiem kryterium (brak elementów władztwa i podporządkowania), choć nie w pełni precyzyjne, stosuje się do odróżnienia stosunków cywilnoprawnych od innych". Dobrymi przykładami mogą tu być sprawy, w których dopuszcza się drogę sądową:

- w sprawie, w której Skarb Państwa po stwierdzeniu nieważności decyzji organu kontroli skarbowej, ustalającej zobowiązanie podatkowe w niższej kwocie od uiszczonej przez podatnika, dochodzi - na podstawie przepisów kodeksu cywilnego o bezpodstawnym wzbogaceniu - zwrotu kwot wypłaconych podatnikowi na podstawie decyzji uznanej za nieważną ${ }^{32}$;

- w sprawie wpływu na skuteczność umowy ustanowienia użytkowania wieczystego uchylenia, stanowiącej przesłankę jej zawarcia, decyzji administracyjnej ${ }^{33}$, które to uchylenie samo przez się nie powoduje nieważności umowy, lecz okoliczności, z powodu których decyzję uchylono, mogą mieć znaczenie dla oceny, w świetle prawa cywilnego, ważności umowy lub dopuszczalności uchylenia się od skutków prawnych zawartego w niej oświadczenia woli ${ }^{34}$.

31 P. Machnikowski, Glosa krytyczna do postanowienia SN z dnia 16 kwietnia 2002 r., V CSK 41/02, OSP 2003, nr 2, poz. 22.

32 Tak uchwała 7 sędziów SN z dnia 16 maja 2007 r., III CZP 35/07, OSNC 2008, nr 7-8, poz. 72; uchwała SN z dnia 6 czerwca 2012 r., III CZP 24/12, OSNC 2013, nr 1, poz. 5; postanowienie SN z dnia 11 września 2014 r., III CZP 46/14, OSNC 2015, nr 7-8, poz. 92; wyrok NSA z dnia 27 października 2011 r., I FSK 1680/10, oba w CBOSA.

${ }^{33}$ Uchwała 7 sędziów SN z dnia 25 kwietnia 1964 r., III Co 12/64, OSNC 1964, nr 12, poz. 244.

${ }^{34}$ Podobnie też uchwała 7 sędziów SN z dnia 28 maja 1992 r., III AZP 4/92, OSNC 1992, nr 12, poz. 211 z glosą krytyczną B. Adamiak, OSP 1993, nr 5, poz. 104; uchwała SN z dnia 2 kwietnia 1993 r., III CZP 34/93, OSNC 1993, nr 10, poz. 177 z glosą aprobującą M. Szewczyk, ST 1994, nr 11, s. 60-63. 
Zatem wbrew uproszczonemu poglądowi zawartemu $\mathrm{w}$ powyższym postanowieniu SN w sprawie V CK 41/02 „ze względu na różnorodność instytucji prawnych, w ramach których powiązanie aktu administracyjnego z innymi zdarzeniami występuje, ustalenie następstw - które mogą być różne - uchylenia (stwierdzenia nieważności) aktu stanowiącego przesłankę powstania zmiany lub ustania danego stosunku cywilnoprawnego nie jest możliwe bez szczegółowej analizy unormowań tych instytucji”"35. Trafnie więc pisze P. Machnikowski, że określenie, iż „akt administracyjny może być zdarzeniem cywilnoprawnym, opiera się na grubym nieporozumieniu. Jest bowiem tak, że rozwiązania problemów na tle skutków, jakie może wywoływać wydanie aktu administracyjnego, należy poszukiwać z uwzględnieniem zasad i instytucji prawa administracyjnego, które są dla tych aktów swoiste" ${ }^{36}$, a nie przechodzić od razu na grunt prawa (przepisów postępowania) cywilnego. Zakwestionować też należy zawarty w powyższym postanowieniu i uchwale Sądu Najwyższego - stanowiącej także podstawę rozważań obu wyroków Trybunału Konstytucyjnego - pogląd, że „o dopuszczalności drogi sądowej rozstrzygają twierdzenia powoda, na których opiera w pozwie swoje roszczenie, nie jest natomiast niezbędne wykazanie istnienia roszczenia oraz stosunku prawnego pomiędzy stronami" ${ }^{37}$. Rzecz jednak w tym, czego nie dostrzeżono w obu glosowanych wyrokach, a także w linii orzeczniczej Sądu Najwyższego ukształtowanej postanowieniem SN w sprawie V CK 41/02, że zgodnie z art. 199 $\$ 1$ k.p.c., sąd odrzuci pozew - tzn. ma obowiązek to uczynić, jeżeli zajdą przesłanki wymienione $\mathrm{w}$ tym przepisie, a więc gdy m.in. droga sądowa jest niedopuszczalna ${ }^{38}$. Jest to bowiem przesłanka nieważności postępowania (art. 379 pkt 1-3 k.p.c.). Brak drogi sądowej sąd ma obowiązek uwzględnić na każdym etapie sprawy (art. 202 k.p.c.), z tym że w wypadku postępowania apelacyjnego i kasacyjnego z uwzględnieniem granic zaskarżenia ${ }^{39}$, jednakże Sąd Najwyższy nieważność postępowania bierze pod rozwagę

35 A. Wolter, J. Ignatowicz, K. Stefaniuk, Prawo cywilne. Zarys części ogólnej, Warszawa 2001, s. 121.

36 Ibidem, s. 120.

37 Podobnie postanowienie SN z dnia 10 marca 1999 r., II CKN 340/98, OSNC 1999, nr 9, poz. 161; postanowienie SN z dnia 22 kwietnia 1998 r., I CKN 1000/97, OSNC 1999, nr 1, poz. 6.

${ }^{38}$ Wyrok SN z dnia 2 czerwca 1965 r., I PR 185/65, Lex nr 5820; postanowienie SA w Łodzi z dnia 5 lipca 2011 r., I ACz 724/11, OSAŁ 2013, nr 1, poz. 3; wyrok SA w Poznaniu z dnia 25 stycznia 2017 r., III AKa 568/16, Lex nr 2265710.

39 Postanowienie SN z dnia 21 maja 2015 r., IV CSK 491/14, Lex nr 1750030. 
z urzędu (art. $398^{13} \$ 1$ k.p.c.), a na te okoliczności odnoszące się do nieważności postępowania może powołać dowody $z$ urzędu ${ }^{40}$. Nie wdając się bardziej w kwestię, czy uwzględnienie z urzędu nieważności postępowania dotyczy wad orzeczenia pierwszej czy drugiej instancji ${ }^{41}$, należy podzielić poglądy M. Michalskiej ${ }^{42}$ i A. Zielińskiego ${ }^{43}$, że skutki nieważności postępowania - bez względu na to, w której instancji wystąpiły - rozciągają się na cały tok postępowania. Sąd Najwyższy, z uwagi na treść art. $398^{13}$ k.p.c., może objąć kontrolą nieważność postępowania pierwszoinstancyjnego w sposób pośredni - poprzez zarzut naruszenia art. $386 \$ 2$ k.p.c. przez sąd drugiej instancji, przez nieuwzględnienie przez niego nieważności postępowania, jaka wystąpiła przed sądem pierwszej instancji ${ }^{44}$. Trafny więc jest pogląd Sądu Najwyższego, że „Konsekwencją właściwości organu administracyjnego [...] jest niedopuszczalność drogi sądowej w tym zakresie. Jeżeli zgodnie $z$ art. $2 \$ 3$ k.p.c. nie są rozpoznawane w postępowaniu sądowym sprawy cywilne przekazane przez przepisy szczególne do właściwości innych organów, to tym bardziej nie mogą być rozpoznane w postępowaniu sądowym [...] sprawy wynikające z legalnych działań organów administracyjnych, których cywilnoprawny charakter może budzić wątpliwości - przy tym wyraźnie poddane właściwości tych organów"45.

Powyższe rozważania prowadzą do wniosku, że pogląd Sądu Najwyższego co do niemożności kontroli pozwu pod kątem dopuszczalności drogi sądowej jest nietrafny, a decydujące są dla tej oceny tylko przytoczone $\mathrm{w}$ pozwie okoliczności faktyczne jako podstawa roszczenia. $\mathrm{Z}$ treści pozwu nie zawsze wynikają twierdzenia o jakimś stosunku prawnym między powodem a pozwanym. Jeżeli kontrola pozwu wykaże, że dług

40 Wyrok SN z dnia 12 października 2016 r., II CSK 58/16, Lex nr 2147278; W. Broniewicz, Uchylenie przez Sąd Najwyższy w trybie kasacji wyroku sądu pierwszej instancji $w$ procesie cywilnym, PS 2002, nr 4, s. 36.

${ }^{41}$ Zob. M. Łochowski, Uchybienia w postępowaniu przed sądem pierwszej instancji stanowiące przyczyny nieważności postępowania jako podstawy kasacji, PS 1999, nr 10, s. 96.

${ }_{42}$ M. Michalska, Zakres rozpoznania sprawy przez Sąd Najwyższy w postępowaniu cywilnym, PiP 2003, nr 10, s. 67-77.

43 A. Zieliński, Glosa krytyczna do wyroku SN z dnia 21 listopada 1997 r., I CKN 825/97, „Palestra” 1998, nr 9-10, s. 202.

44 Tak postanowienie SN z dnia 15 lutego 2000 r., III CKN 1204/99, Lex nr 51569; wyrok SN z dnia 21 listopada 1997 r., I CKN 825/97, OSNC 1998, nr 5, poz. 81 z glosami: aprobującą A. Szpunara, OSP 1998, nr 5, s. 93 i krytyczną A. Zielińskiego, „Palestra” 1998, nr 9-10, s. 202.

${ }^{45}$ Wyrok SN z dnia 9 marca 2007 r., II CSK 457/06, Lex nr 339717. 
wynika z decyzji o odpowiedzialności podatkowej, a pozwany jest osobą trzecią, to pozew powinien być odrzucony. Zauważyć tu trzeba, że skoro dopuszczalność drogi sądowej zależy tylko od twierdzeń powoda, na których opiera on swoje roszczenie, a nie jest uzależniona od wykazania jego istnienia i istnienia stosunku prawnego łączącego strony, nie może być wątpliwości, że to roszczenie musi być wskazane. Można tu tak sarkastycznie powiedzieć, że Sąd Najwyższy dopuściłby możliwość orzekania o ochronie należności podatkowej także w drodze wykorzystania środka prawnego z art. $222 \$ 2$ k.c. (skarga negatoryjna), a przecież powód taki pozew może złożyć i droga sądowa tej ochrony będzie dopuszczalna, gdyż przepisy prawa podatkowego nie zawierają przepisu o treści art. $222 \$ 2$ k.c. Przykładów takich można podać więcej. Jeżeli jest to roszczenie przeciwko jednej z kategorii osób trzecich, o której mowa w art. 107 i nast. ord. pod., to droga jego dochodzenia nie jest dopuszczalna.

Dość często zdarza się też tak, że powód (tu: Skarb Państwa) - bez względu na to, przez kogo jest reprezentowany - w ogóle nie wykazuje, czy uprzednio dochodził zaległości podatkowej ciążącej na osobie trzeciej w toku egzekucji administracyjnej, a nawet nie wykazuje, czy decyzji podatkowej nadał klauzulę wykonalności. W takich przypadkach sąd pierwszej instancji nie może ustalić dopuszczalności drogi sądowej. Na gruncie art. $527 \$ 1$ i nast. k.c. wystarczające będzie bowiem tylko to, czy wierzytelność jest skonkretyzowana (np. w decyzji określającej podatnikowi wysokość zobowiązania podatkowego), ale nie hipotetyczna. Przyjmuje się nawet, że wierzyciel publicznoprawny, tak jak i prywatnoprawny, nie musi dysponować tytułem wykonawczym stwierdzającym obowiązek zapłaty danej wierzytelności ${ }^{46}$. Nie są to jednak poglądy jednolite, albowiem dopuszcza się i wyraża poglądy odmienne, w szczególności takie, że ochronie podlegają też wierzytelności, których tytuł zobowiązania jest niewątpliwy, ale wysokość nie jest jeszcze dokładnie określona, bo za tym przemawia przesłanka niewypłacalności lub wypłacalności zmniejszonej ${ }^{47}$. Tak rozumiane przesłanki i zakres stosowania, niedopuszczalne na gruncie art. 107

46 Zob. wyrok SA we Wrocławiu z dnia 25 września 2013 r., I ACa 788/13, Lex 1392158; wyrok SA w Poznaniu z dnia 26 marca 2013 r., I ACa 460/13, Lex nr 1375822; wyrok SA w Warszawie z dnia 30 stycznia 2014 r., VI ACa 965/13, Lex nr 1489184.

47 Wyrok SN z dnia 13 kwietnia 2011 r., V CSK 313/10, Lex nr 1027200; M. Pyziak-Szafnicka, Ochrona wierzyciela $w$ razie niewypłacalności dłużnika, Warszawa 1995, s. 46; W. Popiołek, [w:] K. Pietrzykowski (red.) (praca zbiorowa), Kodeks cywilny. Komentarz, t. II, Warszawa 2009, s. 207. 
i nast. ustawy - Ordynacja podatkowa, bez wątpienia uprzywilejowują należności publicznoprawne i są przez to wygodne dla organów podatkowych. Taka interpretacja przepisów o odpowiedzialności osób trzecich byłaby na gruncie ustawy - Ordynacja podatkowa i Konstytucji RP niedopuszczalna.

4. Kwestia istotna, niepodnoszona wprost w obu wyrokach Trybunału Konstytucyjnego, dotyczy tego, jaki jest stosunek i zakres regulacji zawartej w art. $527 \S 1$ i nast. k.c. i w art. 107 i nast. ord. pod. Analizy takiej nie dokonują też Sąd Najwyższy i sądy powszechne, opierając się na uproszczonym i z gruntu nietrafnym założeniu, że przepisy ustawy - Ordynacja podatkowa nie zawierają norm przepisów zawartych w art. 527-534 k.c., a co więcej, nie wiadomo, z jakich przesłanek wyprowadzono pogląd, jakoby ustawodawca świadomie pominął instytucję skargi pauliańskiej, która chroniłaby interesy wierzyciela w razie niewypłacalności dłużnika w związku z dokonaniem przez niego w ustawowo określonej sytuacji czynności prawnej z pokrzywdzeniem wierzyciela i uzyskania przez osobę trzecią korzyści majątkowej. Pogląd ten nie został w żadnej mierze uzasadniony, podobnie jak ten, że kwestia ewentualnego rozszerzającego interpretowania przepisów kodeksu cywilnego (a więc jednak istnieje) może być badana dopiero na etapie postępowania rozpoznawczego.

Rzecz jednak w tym, że takich rozważań nie czyni się w żadnej ze spraw rozpoznawanych przez sądy powszechne, a także przez Sąd Najwyższy, notabene zasłaniający się często granicami zaskarżenia. Podkreślić tu trzeba, że argumentacja Trybunału Konstytucyjnego w ogóle nie odnosi się do konkretnych argumentów Rzecznika, wskazujących na szczególne rozwiązania prawne odnoszące się do ochrony należności publicznoprawnych, a w szczególności przysługujące organom podatkowym środki prawne służące do dochodzenia i zabezpieczenia tych należności. W piśmiennictwie szeroko te środki zostały omówione i przedstawione, lecz Trybunał Konstytucyjny ich nie dostrzega ${ }^{48}$. Dlatego też z natury rzeczy pozostawiono na uboczu kwestię rozszerzenia zakresu odpowiedzialności za należności publicznoprawne i tego, czy sytuacja prawna osób trze-

${ }^{48}$ Zob. M. Jasińska, Glosa krytyczna do uchwały 7 sędziów SN z dnia 12 marca 2003 r., III CZP 85/02, „Mon. Praw.” 2004, nr 17, s. 81; B. Brzeziński, M. Kalinowski, Dopuszczalność stosowania skargi pauliańskiej do należności podatkowych, POP 2016, nr 9, s. 211-219; Glosa krytyczna B. Brzezińskiego i A. Nity do wyroku SN z dnia 29 maja 2015 r., V CSK 454/14, POP 2016, nr 4, s. 305-309; S. Babiarz, Skarga pauliańska jako instrument cywilnoprawny ochrony wierzytelności publicznoprawnych, „Kwartalnik Prawa Podatkowego” 2016, nr 4, s. 9-23. 
cich i zakres ich odpowiedzialności za ciężary publiczne uległ tym samym dalszemu rozszerzeniu. Stąd też argumentacja w tym zakresie przedstawiona w uzasadnieniach obu wyroków Trybunału Konstytucyjnego co do tego, że art. $527 \$ 1$ k.c. stosowany do ochrony należności publicznoprawnych nie narusza wynikającej z art. 2 Konstytucji zasady zaufania jednostki do państwa i stanowionego przez nie prawa. Argumentacja zawarta w wyroku Trybunału Konstytucyjnego w sprawie K 52/16 jest wyjątkowo w tym zakresie mglista, niekonkretna i w istocie w ogóle nieprzekonująca.

Nie sposób bowiem zgodzić się z poglądem, że już sam charakter należności, jako element dobra wspólnego, którego strażnikiem są właściwe organy państwa, może prowadzić do dalej idących ograniczeń w dysponowaniu składnikami majątku przez podatnika. Przywołanie tu jako przykładu zastosowania wyroku Trybunału Konstytucyjnego z dnia 11 kwietnia 2000 r., K 15/98, OTK 2000, nr 3, poz. 86, z uwagi na przedmiot oceny konstytucyjności i wzorzec z m.in. art. 31 ust. 3, art. 51 ust. 1 Konstytucji było wyjątkowo niefortunne. Przepisy art. 182 i art. 183 ord. pod. związane są z zagadnieniem tajemnicy bankowej i w żadnej mierze nie przystają do zagadnienia ochrony należności publicznoprawnych i rozszerzenia odpowiedzialności (środków dochodzenia należności publicznoprawnych) osób trzecich.

Chybiony jest też pogląd Trybunału Konstytucyjnego odnoszący się do naruszenia zasady poprawnej legislacji. Podkreślić tu trzeba, że wbrew poglądowi Trybunału Konstytucyjnego to nie ustawodawca odsyła (czy nie odsyła) do regulacji prawnej o niższym standardzie określoności, a odsyła w sposób nieuprawniony orzecznictwo Sądu Najwyższego. Brak tu tylko ustawowej normy dla takiego interpretowania przepisów o odpowiedzialności osób trzecich i przepisów o skardze pauliańskiej.

5. Nietrafna i bezprzedmiotowa jest też argumentacja Trybunału Konstytucyjnego (zresztą spowodowana powierzchownym argumentem Rzecznika) odnosząca się do powiązania kwestii odpowiedzialności osób trzecich, w tym także w wyniku skargi pauliańskiej, z odpowiedzialnością podatkową podatnika i zobowiązaniem podatkowym. Nie można w żadnym razie problemów tych zrównywać, a przedstawienie ich we wniosku dało efekt odmienny od zamierzonego, natomiast związki te trzeba umieć wykazać, wydobyć.

Przede wszystkim podatkowy stan faktyczny ukształtowany przez normę podatkowoprawną determinuje relację prawną pomiędzy podatnikiem a podmiotem uprawnionym $\mathrm{z}$ tego podatku. Jej treścią jest powinność 
poniesienia przymusowego świadczenia pieniężnego, zapłaty podatku. Ten stan faktyczny pośrednio jednak, jak pisze A. Nita ${ }^{49}$, stanowi również fundament innych materialnych powinności podatkowych. Wskutek zobowiązania podatnika powstaje wiele różnorodnych obciążeń dotyczących podmiotów niebędących podatnikami, służących wymiarowi, a także egzekucji należności podatkowej. Należą tu w szczególności obowiązki nałożone na płatnika, inkasenta, spadkobierców (następców prawnych) oraz osoby trzecie ponoszące odpowiedzialność za cudzą zaległość podatkową. Mają one charakter akcesoryjny i nie są zdolne do samodzielnego istnienia w oderwaniu od zdeterminowanej treścią obowiązku podatkowego i podatkowego stanu faktycznego. Dlatego też odpowiedzialność osób trzecich, jako dalsza konsekwencja pojęcia odpowiedzialności podatkowej, nie może nie mieścić się w normie prawnej wywodzonej z art. 217 w związku $\mathrm{z}$ art. 84 Konstytucji, czego wyrazem jest ograniczenie zawarte w art. 107 ord. pod. Zobowiązanie podatkowe jest konsekwencją ciążącego obowiązku podatkowego (art. 4 i art. 5 ord. pod.). Ani jedno, ani drugie nie ciąży na osobie trzeciej. Ordynacja podatkowa, jak wskazuje jej art. 107, zawiera numerus clausus przypadków odpowiedzialności za należności podmiotu pierwotnie zobowiązanego, w których może ta odpowiedzialność być „przeniesiona”. Już tylko ta regulacja, jako szczególna, wyklucza dopuszczalność stosowania w tych przypadkach art. 527 i nast. k.c., zawarte bowiem w przepisach kodeksu cywilnego przesłanki odpowiedzialności osoby trzeciej rozszerzają tę odpowiedzialność na czynności, wskutek których dłużnik stał się niewypłacalny lub wypłacalny w wyższym stopniu.

Takiego określenia przepisy art. 107-119 ord. pod. nie zawierają. Używa się go, ale w nieprawidłowy sposób w orzecznictwie ${ }^{50}$. Odpowiedzialność osób trzecich na gruncie ustawy - Ordynacja podatkowa jest rodzajem odpowiedzialności nieznanym na gruncie prawa cywilnego, solidarnej, o charakterze posiłkowym. Ma ona charakter odpowiedzialności zastępczej, kaskadowy. Te ostatnie cechy zbliżają tę odpowiedzialność do odpowiedzialności na skutek skargi pauliańskiej.

Oczywiście, skarga pauliańska sama przez się nie kreuje - jak pisze Trybunał Konstytucyjny - nowej sytuacji prawno-materialnej w sferze prawa

49 Zob. A. Nita, Wpływ podatkowego stanu faktycznego na zaistnienie stosunku podatkowoprawnego, [w:] idem, Porozumienia $w$ prawie podatkowym, Warszawa, Lex/el, pkt 2.1.2.

${ }^{50}$ Zob. wyrok SN z dnia 30 marca 2017 r., II UK 267/16, Lex nr 2306377; wyrok NSA z dnia 5 marca 2015 r., II FSK 249/13, Lex nr 1666147. 
podatkowego; z natury swojej nie kreuje ani nowego podmiotu odpowiedzialnego, ani w końcu też przedmiotu odpowiedzialności, ale w sposób oczywisty i niewątpliwy kreuje nowy środek odpowiedzialności jednego z podmiotów prawa podatkowego wyłączony z wymogów określoności wskazanych w art. 217 w związku z art. 84 Konstytucji. Przecież z tych przepisów Trybunał Konstytucyjny wywiódł normę ograniczenia ustawodawcy w zakresie stanowienia prawa podatkowego, np. nakaz uwzględniania przez niego zdolności do poniesienia ciężaru podatkowego ${ }^{51}$. Nie można też powiedzieć, że zasada ta nie może odnosić się do osób trzecich, które odpowiadają tylko za zaległości podatkowe podatnika (płatnika, inkasenta, następcy prawnego) na skutek zaistnienia nie zawsze uświadomionych przez siebie przesłanek i okoliczności, nie będąc obciążeni obowiązkiem podatkowym. Należy zwrócić uwagę na to, że art. 84 Konstytucji, czego Trybunał Konstytucyjny nie dostrzegł, chroni nie obowiązki majątkowe podatnika, lecz obywatela, a więc właściwie każdego podmiotu przebywającego na terenie Rzeczypospolitej Polskiej ${ }^{52}$.

6. Przedmiotem oceny Trybunału Konstytucyjnego nie stał się także wzorzec kontroli z art. 32 ust. 1 i 2 Konstytucji. Cechą istotną, różniącą podmioty poddane restrykcjom $\mathrm{z}$ art. 527-534 k.c., jest to, że regulacja ta w świetle wyroku Trybunału Konstytucyjnego w sprawie K 52/16 ma zastosowanie nie tylko do podmiotów prawa prywatnego, ale i prawa publicznego; pomimo wypowiedzi Trybunału, że te drugie działają tu w sferze dominium, a nie imperium, to przecież nie budzi wątpliwości, że ta sfera działania tych podmiotów jest ograniczona tylko do działań związanych z ich udziałem w obrocie cywilnoprawnym, a więc gdy Skarb Państwa występuje jako osoba prawna w sferze uprawnień właścicielskich ${ }^{53} \mathrm{czy}_{\mathrm{w}}$ sferze

${ }^{51}$ Wyroki TK: z dnia 6 marca 2002 r., P 7/00, OTK-A 2002, nr 2, poz. 13, Dz.U. z 2002 r. Nr 23, poz. 242; z dnia 7 czerwca 1999 r., K 18/98, OTK 1999, nr 5, poz. 95, Dz.U. z 1999 r. Nr 52, poz. 545.

52 Tak P. Kociubiński, Ciężary i świadczenia publiczne, [w:] idem, Powojenne przeksztatcenia własnościowe w świetle Konstytucji, Lex/el., pkt 4.3.4.; K. Działocha, [w:] L. Garlicki, M. Zubik (red.) (praca zbiorowa), Konstytucja Rzeczypospolitej Polskiej. Komentarz, Warszawa 2016 , t. 3, s. $1-2$.

53 W. Szydło, Aspekty podmiotowości prawnej Skarbu Państwa, „Acta Universitatis Wratislaviensis" 2008, nr 3048, Prawo, CCCIV; M. Szubiakowski, Glosa krytyczna do postanowienia SN z dnia 28 marca 1995 r., I CRN 24/95, PiP 1996, nr 8-9, s. 167-173; A. Doliwa, Dychotomiczny charakter podmiotowości prawnej Skarbu Państwa (imperium i dominium), „Studia Prawnicze” 2002, nr 3(153), s. 34-49; A Całus, Problematyka prawna 
działalności gospodarczej ${ }^{54}$. W przypadku korzystania ze środka z art. 527 $\$ 1$ k.c. Skarb Państwa w żadnej z tych sfer nie działa. Wykorzystuje ten środek do zwiększenia swoich uprawnień w sferze imperium dla uzyskania uprzywilejowanej pozycji. Podmioty stricte prywatnoprawne nie mogą przecież wykorzystywać dla dochodzenia swych wierzytelności środków przewidzianych w prawie podatkowym. W tym też tkwi rozszerzenie zasady równości i uprzywilejowania Skarbu Państwa ${ }^{55}$. Zauważyć trzeba, że w szeregu wyroków Trybunał Konstytucyjny ${ }^{56}$ wskazywał, iż wkroczenie państwa w sferę działania właściwą dla podmiotów prywatnoprawnych nakłada znaczne ograniczenia na możliwości państwa.

7. Kolejną zasadą konstytucyjną nieuwzględnioną przez Trybunał Konstytucyjny (notabene nieobjętą wnioskiem Rzecznika) jest zasada praworządności (art. 7 Konstytucji). Nie budzi wątpliwości, że do postanowień formułujących wolności lub prawa, jako podstawę skargi konstytucyjnej, należy zaliczyć przede wszystkim przepisy rozdziału II Konstytucji „Wolności, prawa i obowiązki człowieka i obywatela”, jednakże dopuszcza się także poszukiwanie tych praw w rozdziale I „Rzeczpospolita”, który formułuje zasady ustroju państwa. Wśród nich jest też art. 7 Konstytucji, z tym tylko, że powyższy przepis należało przywołać w skardze (wniosku - art. 80 Konstytucji) w powiązaniu z przepisami rozdziału II Konstytucji ${ }^{57}$, a więc np. art. 31 ust. 3 (zasada proporcjonalności), art. 32 (zasada równości), art. 64 ust. 2 (zasada ochrony własności). Z zasady praworządności należy wyprowadzić pogląd powszechnie przyjmowany w orzecznictwie także Trybunału Konstytucyjnego o niedopuszczalności domniemywania kompetencji. Zasady legalności i demokratycznego państwa prawnego wskazują, że organ władzy publicznej może mieć kompetencje do załatwienia sprawy (tu sąd powszechny) wynikającą tylko z wyraźnego przepisu

Skarbu Państwa, „Biuletyn Rady Legislacyjnej” 1995, nr 6, s. 12-37; N. Gajl, Skarb Państwa, Warszawa 1996, s. 90-95.

${ }_{54}$ M. Dziurda, Reprezentacja Skarbu Państwa w procesie cywilnym, Kraków 2005, s. 9.

55 Zob. wyrok TK z dnia 26 listopada 2007 r., P 24/06, OTK-A 2007, nr 10, poz. 126, Dz.U. z 2007 r. Nr 225, poz. 1671.

56 Zob. wyrok TK z dnia 7 maja 2001 r., K 19/00, OTK-ZU 2001, nr 4, poz. 82, Dz.U. z 2001 r. Nr 43, poz. 489 z glosą krytyczną M. Przychodzkiego, „Radca Prawny” 2002, nr 3, s. 97; wyrok TK z dnia 8 października 2007 r., K 20/07, OTK-A 2007, nr 9, poz. 102, Dz.U. z 2007 r. Nr 192, poz. 1394.

57 Tak w: wyroku TK z dnia 10 lipca 2000 r., SK 21/00, OTK 2000, nr 5, poz. 144, Dz.U. z 2000 r. Nr 55, poz. 666; wyroku TK z dnia 29 kwietnia 2003 r., SK 24/02, OTK-A 2003, nr 4, poz. 33, Dz.U. z 2003 r. Nr 83, poz. 773. 
prawa. Kompetencja nie może być wyprowadzona $\mathrm{z}$ innej, rodzajowo podobnej kompetencji ${ }^{58}$, a samoistne znaczenie art. 7 Konstytucji nie może być sprowadzone do dyrektywy interpretacji przepisów kompetencyjnych, co nie jest zakazane, to jest dozwolone. Podobne poglądy są też utrwalone w orzecznictwie sądów administracyjnych ${ }^{59}$. W związku z powyższym chybiony jest argument, że w sprawach ze skargi pauliańskiej Skarb Państwa działający przez określony podmiot (art. $67 \$ 2$ k.p.c., art. 4 ustawy z dnia 15 grudnia 2016 r. o Prokuratorii Generalnej Rzeczypospolitej Polskiej ${ }^{60}$ ) działa jako podmiot nie w sferze imperium, a w sferze dominium. Sam Sąd Najwyższy wielokrotnie wypowiadał następujący podgląd: „Nie ma miejsca na dowolność w posługiwaniu się instytucjami prawa cywilnego w sferze uregulowanej przepisami prawa publicznego"61. Wystarczające zatem byłoby tylko przestrzeganie tej zasady.

8. Generalnie można mieć też wątpliwości co do tego, czy Rzecznik nie powinien był podnieść zarzutu niezgodności art. $527 \$ 1$ k.c. z art. 2 Konstytucji (zasada nadmiernej ingerencji) i art. 31 ust. 3 Konstytucji (zasada proporcjonalności). O ile bowiem test proporcjonalności z art. 2 Konstytucji, jak się przyjmuje w orzecznictwie Trybunału Konstytucyjnego ${ }^{62}$ oraz piśmienni$\mathrm{ctwie}^{63}$, ma o tyle łagodniejszy charakter, że nie stosuje się do niego w spo-

58 Tak TK w wyroku z dnia 10 maja 1994 r., W 7/94, OTK 1994, nr 1, poz. 23, a także w wyroku z dnia 27 maja 2002 r., K 20/01, OTK-A 2002, nr 3, poz. 34.

59 Wyroki NSA: z dnia 11 stycznia 2011 r., II GSK 1365/10; z dnia 13 lipca 2017 r., II OSK 1215/17; z dnia 30 września 2016 r., I OSK 852/15; z dnia 30 maja 2016 r., II OSK 2284/14; z dnia 6 października 2010 r., II OSK 1453/10; z dnia 21 sierpnia 2007 r., I OSK 360/07; z dnia 29 października 2009 r., I OSK 79/09; z dnia 25 września 2009 r., I FSK 1070/08 - wszystkie w CBOSA.

${ }^{60}$ Dz.U. z 2016 r., poz. 2261 z późn. zm.

61 Uzasadnienie uchwały 7 sędziów SN z dnia 21 września 1993 r., III CZP 72/93, OSNC 1994, nr 3, poz. 49; wyrok SN z dnia 17 grudnia 1998 r., I CKN 935/97, OSP 1999, nr 9, poz. 170; postanowienie SN z dnia 28 marca 1995 r., OSNC 1995, nr 7-8, poz. 112; postanowienie SN z dnia 24 września 1965 r., II CR 372/65, OSNC 1966, nr 5, poz. 82 z glosa aprobującą S. Breyera, OSP 1966, nr 11, poz. 244; uchwala SN z dnia 13 maja 1977 r., III CZP 35/77, OSNC 1978, nr 2, poz. 21; K. Piasecki, Kodeks cywilny. Komentarz. Księga pierwsza. Część ogólna, Kraków 2003, Lex/el. komentarz do art. 34 pkt 1.

${ }_{62}$ Zob. wyroki TK: z dnia 12 lutego 2014 r., K 23/10, OTK-A 2014, nr 2, poz. 10, Dz.U. z 2014 r., poz. 236; z dnia 12 marca 2014 r., P 27/13, OTK-A 2014, nr 3, poz. 30, Dz.U. z 2014 r., poz. 375 z glosami: krytyczną A. Skowron, Lex/el. i częściowo krytyczną M. Ożoga, „Przeg. Sejm.” 2015, nr 2, s. 160-172.

63 Zob. L. Garlicki, K. Wojtyczek, [w:] L. Garlicki, M. Zubik (red.), M. Derlatka, K. Działocha, S. Jarosz-Żukowska, A. Łukaszczuk, P. Sarnecki, W. Sokolewicz, J. Trzciński, 
sób rygorystyczny wymagania łącznego spełnienia wymagań przydatności, konieczności i proporcjonalności, co musi mieć miejsce w przypadku art. 31 ust. 3 Konstytucji, a więcej znaczenia pozostawia się domniemaniu zgodności ustawy z Konstytucją ${ }^{64}$. Zauważyć tu też należy, że w wyroku z dnia 9 października 2012 r., P 27/11 ${ }^{65}$, Trybunał Konstytucyjny przypomniał, iż choć zasada proporcjonalności wynika nie tyle $z$ art. 2, ile przede wszystkim $\mathrm{z}$ art. 31 ust. 3, nie oznacza to zaprzeczenia związku istniejącego pomiędzy zasadą proporcjonalności a zasadą demokratycznego państwa prawnego, urzeczywistniającego zasadę sprawiedliwości społecznej, gwarantowaną przez art. 2 Konstytucji. Z kolei w wyroku z dnia 13 marca 2007 r., K 8/0766, Trybunał przyjął, że zarzut nieproporcjonalności kwestionowanego uregulowania może być oparty wyłącznie na naruszeniu art. 2 Konstytucji. Z tym tylko, że jak wynika z lektury dalszej części uzasadnienia tego wyroku, Trybunał Konstytucyjny wskazuje i wiąże tę nieproporcjonalność z „należytym (nienależytym) wyrażeniem celu legislacyjnego i środka użytego do jego realizacji”. Dlatego też w piśmiennictwie ${ }^{67}$ wskazuje się, że „standard ochrony wydobywany $z$ art. 2 Konstytucji jest niższy od standardu wymaganego przez art. 31 ust. 3, gdyż może on pozostawiać władzom publicznym szerszą swobodę działania”. Niestety, w tym kierunku nie poszły działania Rzecznika.

9. W sprawie dopuszczalności stosowania w sprawach ochrony należności publicznoprawnych art. 527 i nast. k.c. powinien też znaleźć zastosowanie wzorzec $\mathrm{z}$ art. 64 ust. 2 w związku z art. 32 ust. 2 Konstytucji. Przepisy konstytucyjne o ochronie własności nie wprowadzają, tak jak zredagowano to w uzasadnieniu wyroku w sprawie K 52/16, szczególnego poziomu ochrony własności publicznoprawnej (art. 1a pkt 13 u.p.e.a. i art. 28 ust. 1 pkt 3 ustawy z dnia 16 listopada 2016 r. o Krajowej Administracji Skarbowej ${ }^{68}$ czynią naczelnika urzędu skarbowego podmiotem uprawnionym do wykonywania zadań wierzyciela należności pieniężnych, a tym samym podmiotem uprawnionym do żądania wykonania obowiązku lub jego zabezpieczenia w administracyjnym postępowaniu egzekucyj-

M. Wiącek, K. Wojtyczek, Konstytucja Rzeczypospolitej Polskiej. Komentarz, t. II, Warszawa 2016, Lex./el komentarz do art. 31 pkt 43.

${ }^{64}$ Wyrok TK z dnia 31 stycznia 2013 r., K 14/11, OTK-A 2013, nr 1, poz. 7, Dz.U. z 2013 r., poz. 193.

${ }_{65}$ OTK-A 2012, nr 9, poz. 104, Dz.U. z 2012 r., poz. 1124.

${ }^{66}$ OTK-ZU 2007, nr 3, poz. 26, Dz.U. z 2007 r. Nr 43, poz. 327.

${ }^{67}$ Zob. L. Garlicki, K. Wojtyczek, op. cit., pkt 43.

${ }^{68}$ Dz.U. z 2018 r., poz. 508 z późn. zm. 
nym lub zabezpieczającym) wobec innych rodzajów własności, zwłaszcza prywatnoprawnej ${ }^{69}$. Wprawdzie w piśmiennictwie takie poglądy się głosi ${ }^{70}$, to jednak sam fakt konstytucyjnego rozróżnienia własności prywatnej, komunalnej oraz własności Skarbu Państwa nie oznacza, że Konstytucja RP uprzywilejowuje którykolwiek z tych rodzajów własności. Zauważyć tu należy, że stosowanie art. $527 \$ 1$ k.c. jako dodatkowego środka prawnego w istocie rzeczy godzi we własność osób fizycznych, ewentualnie osób prawnych. Ta ochrona musi mieć cechę „równości dla wszystkich” tych podmiotów. Nie ma tej równości, gdy w stosunku do niektórych z nich stosowane mogą być środki tylko przepisów ustawy - Ordynacja podatkowa, czy ustawy o postępowaniu egzekucyjnym w administracji, a w stosunku do innych także środki z przepisów Kodeksu cywilnego. Podkreślenia wymaga to, że obie te sytuacje wskazują, iż te grupy podmiotów znajdują się $\mathrm{w}$ sensie przedmiotowym $\mathrm{w}$ tożsamej sytuacji faktycznej (art. 112 ord. pod. i art. $527 \$ 1$ k.c.). Nieuzasadnione uprzywilejowanie podmiotów państwowych, np. uprzywilejowanie Skarbu Państwa $\mathrm{w}$ postępowaniu egzekucyjnym ${ }^{71}$ czy w zakresie pierwszeństwa hipotek Skarbu Państwa ${ }^{72}$, narusza zasadę równej ochrony własności i innych praw majątkowych. Dlatego w orzecznictwie wyrażano trafną myśl: „kontekst historyczny powstania Konstytucji wyjaśnia, że wpisanie zasady równej ochrony do przepisów normujących wolności i prawa człowieka i obywatela ma na celu podkreślenie niedopuszczalności różnicowania ochrony praw majątkowych przez przepisy przyznające państwu i podmiotom publicznym pozycję uprzywilejowaną $\mathrm{w}$ stosunku do osób fizycznych i osób prawnych prawa prywatnego. Zróżnicowanie regulacji środków i zakresu ochrony praw może być natomiast konsekwencją związania podmiotów publicznych, a w szczególności państwowych, normami konstytucyjnymi, które nie odnoszą się do osób prywatnych. Nakaz zapewnienia równej ochrony prawnej, podobnie jak

${ }^{69}$ R. Illinicz, Formy własności w Konstytucji RP z 1997 r., [w:] K. Skotnicki (red.), Własność - zagadnienia ustrojowo-prawne. Porównanie rozwiązań w państwach Europy Środkowo-Wschodniej, Łódź 2006, s. 125.

${ }^{70}$ C. Kosikowski, Zasada ochrony własności, [w:] W. Sokolewicz (red.), Zasady podstawowe polskiej Konstytucji, Warszawa 1998, s. 235.

71 Wyrok TK z dnia 14 maja 2009 r., K 21/08, OTK-A 2009, nr 5, poz. 67, Dz.U. z 2009 r. Nr 81, poz. 687.

72 Wyrok TK z dnia 26 listopada 2007 r., P 24/06, OTK-A 2007, nr 10, poz. 126, Dz.U. z 2007 r. Nr 225, poz. 1671. 
wyrażona w art. 32 zasada równości, nie oznacza zatem pełnej identyczności sytuacji prawnej podmiotów publicznych i podmiotów prywatnych"73.

10. Na koniec nie sposób nie dostrzec, że stanowisko Ministra Finansów zawarte w piśmie z dnia 22 lutego 2016 r., w odpowiedzi na wystąpienie Rzecznika z dnia 25 stycznia 2016 r., jest o tyle nieuzasadnione, że w zbliżonym przypadku - stosowania do podatkowych stanów faktycznych przepisów art. 189 k.p.c. o żądaniu ustalenia przez sąd istnienia lub nieistnienia stosunku prawnego lub prawa, gdy powód ma w tym interes prawny - doprowadził tenże organ do zmian w ustawie - Ordynacja podatkowa i Kodeksie postępowania cywilnego przez dodanie w tych ustawach od dnia 1 września 2005 r. $^{74}$ odpowiednio art. 199a i art. $189^{1}$. Nie było to przy tym tylko „zmniejszeniem wątpliwości niektórych przedstawicieli doktryny”. Choć przed powyższą datą organ podatkowy nie mógł skorzystać z instytucji prawnej uregulowanej w art. 189 k.p.c., gdyż nie miał interesu prawnego ${ }^{75}$, to przecież orzecznictwo sądów administracyjnych nie kwestionowało, że organy podatkowe mogą oceniać skutki podatkowe czynności cywilnoprawnych, a jeżeli do ich oceny niezbędne jest ustalenie stosunku prawnego lub prawa, to także i w zakresie tych kwestii prawnych ${ }^{76}$. Nie było zatem potrzeby dokonywania zmian w przepisach prawa podatkowego, ale jednak ich dokonano.

To tylko tak na marginesie tego sporu.

${ }^{73}$ Wyrok TK z dnia 31 stycznia 2001 r., P 4/99, OTK 2001, nr 1, poz. 5, Dz.U. z 2001 r. Nr 11, poz. 91; wyrok TK z dnia 17 marca 2008 r., K 32/05, OTK-A 2008, nr 2, poz. 27, Dz.U. z 2008 r. Nr 51, poz. 299.

${ }^{74}$ Zob. art. 1 pkt 76 i art. 2 ustawy z dnia 30 czerwca 2005 r. o zmianie ustawy - Ordynacja podatkowa oraz o zmianie niektórych innych ustaw (Dz.U. z 2005 r. Nr 143, poz. 1199 z późn. zm.).

75 Wyrok SN z dnia 7 lutego 2006 r., I PK 209/04, Lex nr 281245; uchwała 7 sędziów SN z dnia 28 września 2005 r., I P 2/05, OSNP 2006, nr 5-6, poz. 71.

${ }^{76}$ Zob. np. wyrok NSA z dnia 18 lutego 1999 r., SA/Bk 1612/97, „Studia Podatkowe” 2001, nr 7, s. 35; wyrok NSA z dnia 28 stycznia 2000 r., I SA/Lu 1432/98, Lex nr 45236; wyrok NSA z dnia 16 czerwca 2005 r., FSK 2052/04, Lex nr 173050. 


\section{BIBLIOGRAFIA}

Babiarz S., Skarga pauliańska jako instrument cywilnoprawny ochrony wierzytelności publicznoprawnych, „Kwartalnik Prawa Podatkowego” 2016, nr 4.

Białogłowski W., Wznowienie postępowania w następstwie wydania przez TK wyroku interpretacyjnego, [w:] M. Bernatt, J. Królikowski, M. Ziółkowski (red.), Skutki wyroków Trybunału Konstytucyjnego w sferze stosowania prawa, „Studia i Materiały Trybunału Konstytucyjnego" 2013, t. XLVII.

Brzeziński B., Kalinowski M., Dopuszczalność stosowania skargi pauliańskiej do należności podatkowych, „Przegląd Orzecznictwa Podatkowego” 2016, nr 9.

Całus A., Problematyka prawna Skarbu Państwa, „Biuletyn Rady Legislacyjnej” 1995, nr 6.

Chauvin T., Stawecki T., Winczorek P., Wstęp do prawoznawstwa, Warszawa 2009.

Doliwa A., Dychotomiczny charakter podmiotowości prawnej Skarbu Państwa (imperium i dominium), „Studia Prawnicze” 2002, nr 3(153).

Działocha K., [w:] L. Garlicki, M. Zubik (red.) (praca zbiorowa), Konstytucja Rzeczypospolitej Polskiej. Komentarz, t. 3, Warszawa 2016.

Dziurda M., Reprezentacja Skarbu Państwa w procesie cywilnym, Kraków 2005.

Gajl N., Skarb Państwa, Warszawa 1996.

Garlicki L., Uwagi o charakterze prawnym orzeczeń Trybunału Konstytucyjnego, [w:] B. Banaszak, J. Trzciński (red.), Studia nad prawem konstytucyjnym, Wrocław 1997.

Garlicki L., Wojtyczek K., [w:] L. Garlicki, M. Zubik, M. Derlatka, K. Działocha, S. Jarosz-Żukowska, A. Łukaszczuk, P. Sarnecki, W. Sokolewicz, J. Trzciński, M. Wiącek, K. Wojtyczek (red.), Konstytucja Rzeczypospolitej Polskiej. Komentarz, t. II, Warszawa 2016; Lex./el., komentarz do art. 31 pkt 43.

Illinicz R., Formy własności w Konstytucji RP z 1997 r., [w:] K. Skotnicki (red.), Własność - zagadnienia ustrojowo-prawne. Porównanie rozwiązań w państwach Europy Srodkowo-Wschodniej, Łódź 2006.

Kociubiński P., Ciężary i świadczenia publiczne, [w:] P. Kociubiński, Powojenne przekształcenia własnościowe w świetle Konstytucji, Warszawa 2013; Lex/el., pkt 4.3.4.

Kosikowski C., Zasada ochrony własności, [w:] W. Sokolewicz (red.), Zasady podstawowe polskiej Konstytucji, Warszawa 1998.

Łochowski M., Uchybienia w postępowaniu przed sądem pierwszej instancji stanowiące przyczyny nieważności postępowania jako podstawy kasacji, „Przegląd Sądowy” 1999, nr 10.

Michalska M., Zakres rozpoznania sprawy przez Sąd Najwyższy w postępowaniu cywilnym, „Państwo i Prawo” 2003, nr 10.

Nita A., Wpływ podatkowego stanu faktycznego na zaistnienie stosunku podatkowoprawnego, [w:] idem, Porozumienia w prawie podatkowym, Warszawa 2014; Lex/el., pkt 2.1.2.

Piasecki K., Kodeks cywilny. Komentarz. Księga pierwsza. Część ogólna, Kraków 2003; Lex/el, komentarz do art. 34 pkt 1.

Pietrzykowski K., O tak zwanych ,interpretacyjnych” wyrokach Trybunału Konstytucyjnego, „Przegląd Sądowy” 2004, nr 3.

Popiołek W., [w:] K. Pietrzykowski (red.) (praca zbiorowa), Kodeks cywilny. Komentarz, t. II, Warszawa 2009. 
Pyziak-Szafnicka M., Ochrona wierzyciela w razie niewypłacalności dłużnika, Warszawa 1995. Szydło W., Aspekty podmiotowości prawnej Skarbu Państwa, „Acta Universitatis Wratislaviensis" 2008, nr 3048, Prawo, CCCIV.

Więcek M., Żółtek S., Skutki wyroków TK o niekonstytucyjności przepisów prawa karnego materialnego, [w:] M. Bernatt, J. Królikowski, M. Ziółkowski (red.), Skutki wyroków Trybunału Konstytucyjnego w sferze stosowania prawa, „Studia i Materiały Trybunału Konstytucyjnego" 2013, t. XLVII.

Wolter A., Ignatowicz J., Stefaniuk K., Prawo cywilne. Zarys części ogólnej, Warszawa 2001. Wronkowska S., Podstawowe pojęcia prawa i prawoznawstwa, Poznań 2005.

Zieliński A., Prawo do sądu a struktura sądownictwa, „Państwo i Prawo” 2003, nr 4.

\section{Commentary to Constitutional Court decisions of 18 April 2018 (K 52/16) AND 10 JULY 2000 (SK 12/99)}

Summary. Both discussed judgments of the Constitutional Court shall be considered as erroneous. The second judgment is to some extent a result of the first one. The thesis of the first judgment was shaped in a scope that is too wide, where it should be limited only to the situation, in which the regulations of the administrative law do not directly protect a given claim and do not grant this protection a judicial channel. This situation led to extending of the competences of the Supreme Court and courts of general jurisdiction onto subsequent civil law institutions, including such situation, when the regulations of the tax law provide for such protection, along with the judicial channel in administrative courts. At this stage it's hard to decide - even though throughout a couple of last years courts of general jurisdiction and the Supreme Court established a certain pattern of judicial decisions - which direction the court rulings would take. Only the Court of Justice of the European Union or intervention of legislators might change the disadvantageous direction, in which the judicial principles go nowadays.

Keywords: actio Pauliana, dominium, imperium, public claims. 